University of Nebraska - Lincoln

DigitalCommons@University of Nebraska - Lincoln

1984

\title{
Tarasoff, the doctrine of special relationships, and the psychotherapist's duty to warn
}

\author{
Robert F. Schopp \\ University of Nebraska-Lincoln, rschopp1@unl.edu \\ Michael R. Quattrocchi
}

Follow this and additional works at: https://digitalcommons.unl.edu/lawfacpub

Part of the Legal Studies Commons

Schopp, Robert F. and Quattrocchi, Michael R., "Tarasoff, the doctrine of special relationships, and the psychotherapist's duty to warn" (1984). College of Law, Faculty Publications. 95.

https://digitalcommons.unl.edu/lawfacpub/95

This Article is brought to you for free and open access by the Law, College of at DigitalCommons@University of Nebraska - Lincoln. It has been accepted for inclusion in College of Law, Faculty Publications by an authorized administrator of DigitalCommons@University of Nebraska - Lincoln. 


\section{Tarasoff, the doctrine of special relationships, and the psychotherapist's duty to warn}

BY ROBERT F. SCHOPP, PH.D., AND MICHAEL R. QUATTROCCHI, PH.D.

Although the legal doctrine of special relationships was a cornerstone of the Tarasoff decision, the authors argue that the conceptual relationship among that doctrine, the documented inability to predict violence, and the duty to warn is such as to preclude the foundation of a duty to warn on the doctrine of special relationships.

I.

The California Supreme Court, in its controversial Tarasoff decision, ruled that a psychotherapist may be found negligent when he fails to prevent his patient from harming someone.

When a therapist determines, or pursuant to the standards of his profession should determine, that his patient presents a serious danger of violence to another, he incurs an obligation to use reasonable care to protect the intended victim against such danger. The discharge of this duty may require the therapist to take one or

AUTHORS' NOTE: The authors are indebted to Haig Katchadourian for his valuable comments on an earlier draft of this article.

(ㄷ) 1985 by Federal Legal Publications, Inc. 
more of various steps, depending on the nature of the case. Thus it may call for him to warn the intended victim or others likely to apprise the victim of danger, to notify the police, or to take whatever other steps are reasonably necessary under the circumstances.'

The court based this decision on the doctrine of special relationships, which provides a basis for the duty to control the behavior of third parties, and on the policy considerations involved in protecting the public from dangerous assault. The reasoning presented by the court in Tarasoff has been accepted by courts in Pennsylvania, Nebraska, and New Jersey. ${ }^{2}$

The Tarasoff decision evoked considerable controversy and numerous commentaries, many of which discussed the adequacy of professional standards for the prediction of dangerousness or the policy considerations involved in the decision. ${ }^{3}$ The most commonly identified policy issue concerned the debate over whether warning the potential victim would increase or decrease the probability of harm. ${ }^{4}$ The competing public interest in promoting effective psychotherapy (particularly for potentially dangerous patients) and the role of confidentiality in this interest also received significant attention. ${ }^{5}$

There remains a rather puzzling aspect of the court's decision which has not been resolved in the Tarasoff literature. The court defined a duty for a therapist who determines or should determine that his patient presents a serious danger of violence when it had already cited a strong body of evidence demonstrating that therapists cannot determine this; i.e., the court simultaneously declared that therapists must act upon a judgment and acknowledged that this judgment lies beyond the capacity of the profession. ${ }^{6}$ It is important to note that the court did not refute or even question this evidence. Rather, the court cited the doctrine of special relationships as the source of a duty to control 
third parties, argued that the psychotherapist's diagnosis and prediction of danger are comparable to judgments that doctors and other professionals must regularly make, and concluded that therapists must predict and warn to the standards of the profession.?

Hence, the doctrine of special relationships is the cornerstone of the court's argument in favor of a duty to warn. While the court definitely asserts that the psychotherapeutic relationship is such a special relationship, it does not indicate exactly what makes a relationship special in this sense or what it is about psychotherapy that renders it such a relationship.

This article will concentrate on this specific aspect of the Tarasoff decision. We will advance an analysis of the doctrine of special relationships as contained in the sources cited by the Tarasoff court in order to determine whether the psychotherapeutic relationship falls within the scope of this doctrine and, if so, what duties follow. We will argue that the conceptual relationship among the doctrine of special relationships, the duty to warn, and the inability to predict is such that when clearly explicated and interpreted in light of the psychotherapist's inability to predict, this doctrine cannot be appropriately applied and, hence, it cannot provide a foundation for a duty to warn or for any other duty which presupposes a capacity to predict.

II.

The facts of the Tarasoff case have been widely reported and discussed; consequently, only a brief summary will be included here. Prosenjit Poddar allegedly informed a psychologist employed by the University of California that he intended to kill Tatiana Tarasoff when she returned from a summer vacation. Poddar was a voluntary outpatient involved in psychotherapy with the psychologist. While Tarasoff was not identified by name, it was alleged that she was 
easily identifiable by description. The psychologist, in consultation with others in his deparment, decided that Poddar should be committed to a mental hospital for observation. The psychologist communicated this decision to the campus police, who in turn detained Poddar briefly, and then released him when, in their judgment, he appeared to be rational. The director of the Department of Psychiatry at the university hospital then ordered that no further attempt be made to have Poddar detained. Poddar killed Tarasoff when she returned approximately two months later, and her parents sued the psychologist and his colleagues who had been involved in the case for negligent failure to warn the victim, or others likely to warn her, of the danger. The California Supreme Court decided in favor of the family on this issue and, in doing so, established the duty described at the beginning of this article. ${ }^{8}$

The court reasoned that the defendant-therapists were negligent in failing to fulfill an obligation incurred in the psychotherapeutic relationship. Negligence in the practice of a profession involves the failure to carry out an obligation to a standard of competence and care that is required of those who are recognized as qualified in that profession and a causal connection between this failure and harm suffered by another. ${ }^{9}$

In order for there to be negligence, there first must be a duty. Under the common law, one person generally has no obligation to control the conduct of a third person. ${ }^{10}$ However, the doctrine of special relationships provides an exception to this general rule in those situations in which:

(a) a special relation exists between the actor and the third person which imposes a duty upon the actor to control the third person's conduct, or

(b) a special relation exists between the actor and the other which gives to the other a right to protection." 
The Tarasoff court employed this doctrine as the source of a therapist's duty to prevent his patient from harming another. The court cited several precedent cases in which physicians and other professionals had been held liable for failing to take reasonable care to control others and concluded that these precedents were correctly applied to the instant case and hence that psychotherapists have a duty to prevent their patients from causing harm to others. ${ }^{12}$ Several of the cases cited involved physicians who had been found negligent for failure to warn others of the dangers emanating from the illnesses of their patients and the court concluded that psychotherapists also have an obligation to prevent harm through warnings issued to potential victims.

In citing the doctrine of special relationships as the source of the duty to prevent harm, the court relied heavily on the Restatement (Second) of Torts and a seminal article by Harper and Kime. ${ }^{13}$ The Restatement (Second) of Torts provides an analysis of four different types of relationships which are identified as Type A relationships and which are analogous to four subsets of cases identified by Harper and Kime. These involve the following: parent and child, master and servant, possessor of land or chattels and licensee, and, finally, those in charge of dangerous persons. The duty does not rise purely from the existence of these relationships; rather, certain conditions must be met in any specific case. In each case, the actor who is participating in one of these relationships has a duty to control the third person only if (1) the actor knows or has reason to know that he has the ability to control the third party, and (2) the actor knows or should know of the necessity and opportunity for exercising such control. ${ }^{14}$ However, the principle which describes Type A cases and which was quoted above from the Restatement (Second) of Torts only states that there is a duty to control third persons in those relationships which impose such a duty. It provides no general rules by which to identify such relationships. 
Harper and Kime report a series of cases in which the actor was held liable for failure to control a third party, and they argue that these cases were bound together by the nature of the relationships between the actors and the third parties. They conclude that an actor has a duty to control the behavior of a third party in order to prevent danger to another if the actor is in some special relationship with the third person, ". . . . which gives him a peculiar ability to affect that person's conduct."'s

This review of the doctrine of special relationships, as presented by Harper and Kime and the Restatement (Second) of Torts, reveals that a principle can be abstracted which integrates these two sources and identifies the elements a case must include in order to fall within the scope of this doctrine. We would like to advance the following formulation of that principle.

[1] An individual $(A)$ has a duty to conduct his relationship with a third person $(B)$ in such a manner as to take reasonable care to control the conduct of $B$ in order to prevent $B$ from causing harm to another $(C)$ just in case $A$ stands in a special relationship to $B$ such that: (1) the nature of that relationship provides $A$ with some peculiar ability to control the conduct of $B$, (2) $A$ knows or should know that he has the ability to control $B$; and (3) $A$ knows or should know of the necessity and opportunity for controlling $B$.

Having identified the doctrine of special relationships as the source of a duty to control the conduct of third persons, the Tarasoff court then offered a series of precedent cases in order to establish that doctor-patient and, thus, therapist-patient relationships fall under the scope of this doctrine. We will review these cases in order to determine whether they are consistent with the doctrine of special relationships as represented by [1] (and, thus, by the authorities cited by the Tarasoff court). 
III.

The cases cited by the court described a variety of relationships which can be roughly divided into those in which the actor had custody of the third person and those in which there was no custody. Some custodial cases were primarily concerned with decisions to discharge patients from inpatient care following inadequate consideration of their dangerous propensities or with refusal to hospitalize a prospective patient who had been identified as homicidal. ${ }^{16}$ Other cases involved hospitals that failed to take reasonable care to prevent patients from self-injury through suicide or escape attempts." In other custodial cases, physicians and others were declared negligent for their failure to communicate their knowledge of the dangerous propensities of patients when they transferred these patients to the custody or care of another. ${ }^{18}$ The court also cited cases in which nonmedical institutions had been held liable for releasing dangerous inmates without warning potential victims who were readily identifiable. ${ }^{19}$ Finally, the court cited two cases in which the guardians of dangerous minors failed to take reasonable care to prevent these minors from harming others. $^{20}$

All of these cases involved situations in which the actor had custody or the opportunity and responsibility to assume custody of the dangerous third person by virtue of the actor's role in a professional (or parental) relationship with the third person. In all cases, the actor had access to information regarding recent dangerous behavior which would have led a reasonable person to be aware of the danger and of his opportunity to control the dangerous person by carefully executing custodial responsibilities. Hence, all of these cases fall within the scope of [1] by the nature of the relationship between the actor and the third party.

The Tarasoff case involved an outpatient and the court cited other cases in order to establish its contention that similar 
duties applied to patients who are not in custody. Two cases involved some overt action by a physician which contributed to the danger. In one of these, a drug was prescribed without the appropriate warnings regarding side effects, while in the other a physician inaccurately advised the patient that he could safely drive. ${ }^{21}$ Several noncustodial cases were incidents in which physicians had failed to diagnose a contagious disease or, having diagnosed it, failed to issue the appropriate warnings to potential victims or authorities. ${ }^{22}$ In all of these cases, the diagnosis, in the court's opinion, should have been made through the exercise of reasonable care and ordinary competence. The physicians in these cases did not have physical control of the patients but they did possess, by virtue of their professional training, the knowledge which provided them with a peculiar ability to perceive the danger to others and to eliminate or reduce this danger by communicating this information to potential victims or appropriate authorities.

Although these noncustodial cases were presented by the Tarasoff court as ones in which the doctrine of special relationships applied, they are not easily reconciled with this doctrine as represented by [1]. In order to accommodate these cases, the conception of "a peculiar ability to control" would have to include not only those situations in which the actor has an ability to control the conduct of the third party, but also those in which the actor possesses some capacity to influence potential harm caused by the third party through the application and communication of special knowledge. Hence, a doctrine of special relationships that can accommodate both [1] (which has been distilled from Harper and Kime and the Restatement (Second) of Torts) and the full array of precedent cases cited by the Tarasoff court would have to apply to relationships in which the actor has either some peculiar ability to control the conduct of the third party or some peculiar ability to influence potential harm done by the third party through means other than controlling his conduct. 
In light of the above analysis, we would like to advance the following derivative of [1] as a proposed working formulation of the principle which underlies the doctrine of special relationships as it has been formulated by Harper and Kime and the Restatement (Second) of Torts and as it has actually been applied to professional relationships by the courts which ruled on the precedent cases cited by the Tarasoff court.

[2] A professional $(P)$ has a duty to conduct his professional relationship with a third person $(B)$ in such a manner as to exercise reasonable care to prevent harm to others potentially caused by $B$ just in case the nature of this relationship is such that: (1) the practice of $P$ 's profession provides him with some special ability to decrease the probability of harm potentially caused by $B$; (2) $P$ knows or should know that he has this ability; and (3) $P$ knows or should know of the necessity and opportunity for influencing the harm threatened by $B . .^{23}$

In summary, we have attempted to derive a principle which captures the essential elements of the doctrine of special relationships as applied to Type A special relationships by the various sources cited by the Tarasoff court. Harper and Kime stated that the central issue addressed by the doctrine of special relationships is one of negligence. ${ }^{24}$ As stated previously, negligence in the practice of a profession involves the failure to carry out an obligation to a standard of competence and care required of those practicing that profession. Should $P$ 's profession provide a special capacity to influence harm, then he violates the ordinary competence provision if he lacks this capacity; if he possesses it but fails to exercise it, then he falls short of the reasonable care requirement. Therefore, [2] conceptualizes the doctrine of special relationships as an extension of the general principle of negligence. In the next section, we will apply [2] to the practice of psychotherapy in order to determine whether psychotherapy falls within the scope of the doctrine of special relationships and, if so, whether the duty prescribed by the Tarasoff court is appropriate. 
IV.

Attempts to develop a generally inclusive definition of psychotherapy have met with considerable controversy. However, the following has been suggested as a "generic" definition. "Psychotherapy is (1) a relation among persons, engaged in by (2) one or more individuals defined as needing special assistance to (3) improve their functioning as persons, together with (4) one or more individuals defined as able to render such special help." 25 The therapist is generally expected to be a trained professional who has developed a command of a body of knowledge and proficiency in a series of techniques which are applied within the context of a professional relationship. While proponents of various theoretical orientations may differ regarding specific details, most would agree that successful therapy depends on both expertise and relationship. ${ }^{26}$

The first requirement of [2] is that the substance of the profession in question must provide some peculiar capacity to influence the harm done by others. What if any such capacity is provided by the substance of psychotherapy? The Tarasoff decision called for action including warnings to prevent harm when the therapist knew or should have known of danger. Clearly, warning does not constitute a special ability; it is a technique which presupposes certain capacities. The court's argument in favor of a duty to warn for psychotherapists relied heavily on the duty to warn, which is well established for physicians dealing with dangers emanating from physical diseases. The duty to warn in these cases arises from the physician's special knowledge of physical diseases, which allows him to foresee harm when the ordinary man would not, and hence provides him with a special capacity to prevent harm through the communication of this knowledge. In a like manner, the court held that therapists should be expected to communicate special knowledge of dangerousness which they have or should have by virtue of their professional role. 
The court stated that warnings should not be issued in response to every threat; rather, the therapist is to differentiate innocuous threats from those which pose a real danger. "Certainly a therapist should not be encouraged routinely to reveal such threats . . . . To the contrary, the therapist's obligation to his patient requires that he not disclose a confidence unless such disclosure is necessary to avert danger to others . . . ."27

Such a duty clearly presupposes an ability to predict dangerous behavior with a considerable degree of accuracy. The court recognized the fact that therapists are not able to predict dangerousness with scientific certainty, and required only that they predict with the degree of skill, knowledge, and care demanded by the standards of the profession. Unfortunately, a rather large and consistent body of empirical evidence indicates that the standards of the profession include no ability to accurately predict dangerous behavior. Not only have psychologists and psychiatrists been unable to predict dangerousness to a degree of accuracy which would justify infringing on a client's rights, they have been unable to predict any more accurately than have nonprofessionals. ${ }^{28}$

Strictly speaking, this research regarding the therapist's ability to predict dangerousness is not directly applicable to the Tarasoff situation. Most prediction studies have involved the accuracy of predictions of dangerousness related to admission/discharge decisions with patients who had been previously committed, evaluated for commitment, or in some way identified as dangerous (frequently by past dangerous acts). Consequently, the reasonable conclusion appears to be that we have no data directly regarding the ability of therapists to predict dangerousness in Tarasoff-like situations, and the most nearly applicable data which are available consistently support the contention that the substance of the profession provides no ability to predict and therefore no special ability to influence potential harm 
through warnings or other actions predicated upon predictions..$^{29}$ Hence, the application of [2] to the psychotherapeutic relationship demonstrates that psychotherapy lacks one of the fundamental elements required by the doctrine of special relationships to justify a duty to influence potential harm through warning.

This analysis rejects the court's decision requiring therapists to prevent harm by foreseeing danger and issuing warnings because the special capacity presupposed by this technique does not exist. However, it does not follow from this analysis that psychotherapy is not a Type A special relationship by virtue of some other capacity. It only follows that this specific duty is not accurately founded. We will briefly review the function and effectiveness of psychotherapy in order to determine whether there is some other special capacity which might appropriately place psychotherapy within the scope of [2] and hence give rise to some duty to prevent harm.

Wolman describes psychotherapy as: ". . . a more or less systematic attempt to help a patient achieve maturity, autonomy, responsibility, and skill in adult living." ${ }^{30}$ While the issues involved in psychotherapy outcome research are complex and controversial, there is a growing body of research in support of the hypothesis that those who receive psychotherapy exhibit more measurable improvement than those in no treatment or placebo control groups. ${ }^{31}$

Unfortunately, outcome studies vary widely in the nature of their dependent variables and methods of measurement. Most of the currently available research provides only general information regarding the effectiveness of a variety of therapeutic approaches with many different types of clients and target problems. Consequently, this research does not indicate the degree to which psychotherapy may be an effective means of preventing any particular type of dangerous behavior by any identifiable subset of clients. ${ }^{32}$ However, 
there is some evidence to support the efficacy of certain therapeutic approaches to anger control ${ }^{33}$ Due to the general nature of the available data regarding therapeutic effectiveness, any claim that psychotherapy can serve the specific purpose of preventing dangerous behavior must remain tentative. However, to the degree that psychotherapy can have a positive effect on the client's tendency to function within the broad constraints of societal limits on dangerous behavior, the competent and responsible practitioner of psychotherapy possesses a peculiar capacity to influence the potentially harmful behavior of his client. This capacity is a function of his expertise in the field of psychotherapy; the therapist exercises this capacity through the competent and responsible pursuit of the therapeutic endeavor. This requires a general awareness of the processes of psychotherapy and of the dangers inherent in certain sorts of intrapersonal dynamics and interpersonal situations. However, it does not require the ability to predict a specific harm to a specific victim. To the extent that psychotherapy can develop socially acceptable modes of interaction, this capacity to influence the likelihood of harm can be exercised despite the therapist's inability to predict violence because he can promote generally safe patterns of behavior. Finally, the therapist can and should be aware of the general necessity and opportunity to practice his profession in such a way as to decrease the likelihood of violent behavior despite the inability to predict such behavior in a specific situation.

Given the assumption that effective psychotherapy can be useful in decreasing a patient's tendency toward dangerous behavior, the application of [2] to psychotherapy would yield the conclusion that the psychotherapeutic realtionship is a Type A special relationship that engenders a responsibility to influence the potentially dangerous behavior of a third person (the client). This influence must be exercised through the skillful and careful practice of psychotherapy which is the substantive special ability that underlies the special responsibility and places the psychotherapeutic relationship within the scope of the doctrine of special relationships. 
Admittedly, it will be very difficult to accurately define and apply professional standards for this duty. As stated previously, virtually all theories of psychotherapy agree that successful therapy requires both technique and relationship. Adequate knowledge and command of therapeutic techniques may be relatively amenable to specification (although even this aspect raises significant problems). However, relationship issues are much more difficult to isolate as they involve not only capacities and actions of the therapist, but also the compatibility of the participants. Despite the inherent difficulties involved in developing professional standards for the responsible practice of psychotherapy, this appears to be a much more viable and justifiable option than the Tarasoff court's decision to invoke a duty to warn involving unspecified professional standards and presupposing an admittedly nonexistent capacity.

In summary, we have argued that the doctrine of special relationships is most accurately seen as an extension of the more general principle of negligence. To the extent that a profession provides some special capacity to influence the potential harm done by a client to another, then the professional has the obligation to exercise this aspect of his profession with skill and care just as he is obligated to practice the other aspects of his profession. Hence it is primarily the possession of some special capacity to influence potential harm which renders any profession an appropriate subject of the doctrine of special relationships. Given the existence of such a special capacity and thus the duty to prevent harm, the professional is obligated to employ all the skills he has or a member of his profession should have in the pursuit of this duty.

However, the duty to warn is predicated upon a special capacity to predict dangerous behavior to some acceptable degree of probability and the available evidence strongly supports the contention that this capacity does not exist. Therefore, the Tarasoff court's assertion that the doctrine of 
special relationships is applicable to psychotherapy as a foundation for a duty to warn (or any other duty based upon a capacity to predict) was erroneous in that the special capacity necessary to the appropriate application of this doctrine as a foundation for this duty is absent. Therefore, the court has provided no basis for a duty to control third persons or to influence the harm they may cause.

We have proposed an alternative special capacity (i.e., the ability to decrease the tendency toward dangerous behavior through the competent practice of psychotherapy) which may provide the foundation for inclusion of the psychotherapeutic relationship within the scope of the doctrine of special relationships. If the rather tenuous data in support of this capacity are sufficient for inclusion under the doctrine of special relationships (as we believe they are), then the duty to prevent harm through the careful and competent practice of therapy would follow, but a duty to predict and warn would not. If these tenuous data are not sufficient, then we can see no basis for including psychotherapy under the doctrine of special relationships and thus no foundation for a duty to control third persons or influence the potential harm they may cause.

It may be prudent to anticipate several apparent objections to this conclusion. The first relies on established judicial practice and argues that this alleged inability to predict is inconsistent with years of practice during which psychologists and psychiatrists have testified regarding dangerousness for the purpose of involuntary commitment. This may well be a telling blow but, if so, it has struck the wrong target. We would contend that when a strong body of empirical data contradicts a common practice, the reasonable response is to alter the practice, not to ignore the evidence. Some involuntary commitment laws have already recognized this fact and have defined dangerousness for purposes of com- 
mitment in terms of a recent pattern of dangerous acts or threats rather than as a matter to be determined by professional testimony. ${ }^{34}$

An alternative strategy might be to accept the fact that there is no evidence of a special ability to predict but argue that the psychotherapeutic relationship provides special access to threats, and hence an unusual opportunity to be aware of impending harm which can be prevented through warning. One obvious response is that we have no evidence to support the contention that warnings decrease rather than increase the likelihood of violence.

However, there is a more fundamental contradiction in the "special access" argument. If this special access exists, it is apparently a function of the private nature of the psychotherapeutic relationship in which intimate disclosures of many kinds occur. Most clients enter psychotherapy with the understanding that such information is confidential and hence may be communicated without fear of publicity or penalty. Should the therapist choose to convey such statements to others in the form of a warning, he is quite likely to foreclose his access to sensitive information and hence preclude those conditions which allegedly make the relationship special in this sense (i.e., in the sense of providing special access to threats). ${ }^{35}$

It is widely accepted that successful psychotherapy requires a trusting relationship which includes the belief that intimate revelations will be held in confidence. The practice of divulging these disclosures through warnings (if commonly accepted) may be expected not only to impair a particular therapeutic relationship, but also to prevent other potentially dangerous clients from entering therapy or from fully engaging in it, particularly in light of the fact that ethical principles require that clients be informed of the limits of confidentiality. ${ }^{36}$ Perhaps more importantly, to the extent that it impaired the therapeutic endeavor, this practice would 
prevent the therapist from protecting others through the method he does have at his disposal and which, we have argued, he has a duty to exercise, i.e., the skillful and careful practice of psychotherapy.

One might reply that confidentiality in psychotherapy has never been absolute and the duty to warn applies only in that limited number of cases in which the danger to others is imminent. However, it must be remembered that this special access to threats provides no additional assistance in differentiating those which are likely to be carried out from those which are not and, consequently, the therapist remains incapable of delivering the required predictive accuracy. Hence, there is no way to identify those situations in which the danger is imminent. Should the duty to warn be generally enforced, then in order to avoid liability, therapists would be likely to respond as they have in studies involving admission/discharge decisions-they would grossly overpredict danger.

A proponent of the duty to warn might claim that the foregoing arguments have not really refuted the duty to warn at all but simply established that the professional standards for predictive accuracy would have to be quite low. This proponent would remind us that in the Tarasoff case, the therapist did predict violence and the fact that sometimes therapists do predict violence surely demonstrates that at least in these cases they can do so. Shouldn't the therapist therefore have a duty to warn when he does predict violence? ${ }^{37}$

No, the therapist should not have a duty to warn when he does predict violence because in this situation the fact that a therapist does predict violence does not imply that he can predict it. The source of this apparently contradictory situation lies in an equivocation regarding the term "predict" that pervades the Tarasoff literature. Three distinct meanings of 
"predict" have been used, and frequently confused, in discussion of the duty to warn. In the weakest sense of the word, to predict is simply to identify (overtly or covertly) an expectation. In this sense virtually anyone can predict virtually anything, and to predict in this manner suggests absolutely nothing about accuracy or expertise. Clearly, the ability to predict in this sense provides no foundation for a duty to warn and no capacity to issue warnings with any accuracy or utility. To predict in a second and stronger sense is to foretell accurately, i.e., to identify an expectation which turns out to be true. Unfortunately, predictions of this type are also irrelevant to a duty to warn because they can be differentiated from predictions in the first sense only in retrospect. However, there is a third meaning of "predict" which is relevant to the duty to warn. To predict in this sense is to infer to some identifiable level of confidence on the basis of some combination of empirical data and law-like generalizations. Ideally, such inferences are generated from scientific laws which are based on empirical research and provide some quantitative statement of probability as well as an explanation of the phenomena in question. For practical application, predictions based on consistent correlations can be useful even if an explanation is not presently available. For example, a physician may be able to accurately predict on the basis of observed correlation that his patient will be highly contagious when that patient demonstrates symptom pattern $X$, despite the fact that the physician has no idea what causes this pattern or how it is communicated.

It is this capacity to predict in the third and strongest sense which is relevant to the doctrine of special relationships and the duty to warn, because it is only the capacity to predict in this sense that provides the special ability to influence harm through accurate prediction and warning. Throughout the remainder of this article, "predict" will be used only in this sense. ${ }^{38}$ When the substance of a profession provides the special knowledge necessary to predict some identifiable 
outcome on the basis of some specifiable prior observations to some stipulated level of confidence, then a competent and careful practitioner of that profession can reasonably be expected to make the relevant observations, draw the appropriate inferences, and take whatever action is professionally and legally acceptable. If this particular ability to predict constitutes a "special ability" to prevent harm, then it serves to bring that profession within the scope of the doctrine of special relationships and, if a warning is a viable method of preventing harm, then a duty to warn may well be appropriate.

The level of confidence necessary to give rise to a duty to warn may vary considerably on the basis of such considerations as the likely effects of warnings (both accurate and inaccurate) and the availability of alternatives. The level of confidence necessary to justify a duty to warn would have to be determined by the courts and legislature in light of societal values and the expected effects. However, it hardly seems plausible that the minimal levels of confidence described earlier ${ }^{39}$ could be seen as sufficient to establish a duty to warn in Tarasoff-like situations, particularly in light of the serious possibility that warnings may increase rather than decrease the overall likelihood of violence..$^{40}$

The Tarasoff case may provide an unfortunate demonstration of the potential ramifications of failing to distinguish among these three meanings of "predict." The Tarasoff therapist apparently did identify his expectation that violence was likely. However, it is impossible to determine whether or not that expectation was accurate at the time he formed it, because he took action based on his expectation which may well have contributed to Poddar's action. His attempt to hospitalize Poddar may have resulted in additional humiliation as well as alienation from therapy and consequently increased the probability of violence. Admittedly, this is speculative but it is precisely this indeterminate 
nature of the situation which is at issue. The Tarasoff case aptly demonstrates that neither the fact that the therapist expected violence nor the fact that he foretold it implies that he was able to predict it. Furthermore, even in retrospect we are unable to determine whether his expectation (and his subsequent action) accurately foretold the danger or actively enhanced it. The important point here is that the court's decision was based partially on the presumed societal benefits of warnings, but neither the facts of the case nor any available empirical evidence provides any reason to presume that the effects of such actions would be beneficial. Rather, it remains a controversial empirical question whether warnings would increase or decrease the probability of danger.

This situation stands in stark contrast to that of the physician who may be expected to accurately predict the probability of infection because it is the disease, which his training enables him to diagnose, which is the source of the danger. However, when dealing with psychological dysfunction, it is the person, not the disorder, who is dangerous and violence has not been associated with any particular diagnosis by scientific explanation, or even by close statistical correlation. ${ }^{* 1}$ Therefore, for the psychotherapist (as opposed to the physician dealing with physical disease), competency as a diagnostician entails no capacity to predict danger.

Why, then, does it seem so abhorrent to say that the therapist should not have a duty to warn when he does expect violence? We would like to suggest a three-part answer to this question. The first is to be found in the equivocation described above which promotes the illusion that therapists who expect violence can predict it and thus are in a position to warn accurately. The second is the majority's unquestioned but unsubstantiated assumption that warnings will prevent rather than promote harm. The conjunction of these two factors provides the illusion that the therapist who expects violence can warn as a reliable 
method of decreasing the danger. This illusion takes on particular significance in light of the third factor, which is that it seems morally repugnant to allow an innocent to be harmed when we can prevent it without risk to ourselves, regardless of whether we are engaged in a professional relationship with them. However, this repugnance is more accurately seen as atttached to the legal rule that there is no duty to prevent harm by others, ${ }^{42}$ and it cannot be adequately addressed through distortions or misapplications of the doctrine of special relationships.

Suppose that psychotherapists developed the capacity to predict violence to some acceptable level of confidence. Should there then be a duty to warn? The doctrine of special relationships would provide a foundation for the duty to warn but if the court based its decion partially on policy considerations (as the Tarasoff court did) the likely conclusion is far from obvious. The calculation of the balance of policy considerations would require assumptions regarding several empirical issues about which our knowledge is incomplete. Among these unanswered questions are the following: (1) Would warnings increase or decrease the probability of violence (in this particular case and in general)? (2) What would be the effect on the participation in and benefit from psychotherapy? (3) What is the potential of psychotherapy to deter violence? (4) How do psychotherapy and warnings compare as means of preventing violence? Depending on the available data regarding such questions, it is conceivable that psychotherapists might be exempt from a duty to warn even if such a duty existed for the population in general. Our claim here is not that psychotherapists should not have a duty to warn if the ability to predict is developed, but only that it is not obvious that they should.

Finally, one could argue that the attempt to define psychotherapy as a Type A special relationship was misguided; 
it is really a Type B special relationship based on a professional's general obligation to the community he serves. ${ }^{43}$ However, the professional can only fulfill his general obligation to society (as he can fulfill the specific one to his client) by exerting due care in the exercise of those skills that his profession provides, and it has been established that the ability to predict is not among these.

Notes 1. Tarasoff v. Regents of University of California, 17 Cal. 3d 425, 551 P.2d 334, 131 Cal. Rptr. 14 (1976).

2. Leedy v. Hartnett, 510 F.Supp. 1125 (M.D. Pa. 1981); Lipari v. Sears Roebuck \& Co., 497 F. Supp. 185 (D. Neb. 1980); McIntosh v. Milano, 168 N.J. 466, 403 A.2d 500 (1979)

3. Tarasoff, $131 \mathrm{Cal}$. Rptr. at $\mathbf{3 3}$ (Mosk, concurring and dissenting) \& 34 (Clark, dissenting). See generally J. J. Cocozza \& H. J. Steadman, The Failure of Psychiatric Predictions of Dangerousness, 29 RUTGers L. Rev. 1084 (1976); S. R. Smith, Constitutional Privacy in Psychotherapy, 49 GEO. WASH. L. REV. 1 (1980); A. Stone, The Tarasoff Decision: Suing Psychotherapists to Safeguard Society, 90 HARv. L. REv. 358 (1976); Discovery of Psychotherapist-Patient Communications after Tarasoff, 15 SAN DIEGO L. REv. 265 (1978); Imposing a Duty to Warn on Psychiatrists-A Judicial Threat to the Psychiatric Profession, 48 U. COLO. L. REv. 283 (1977) [hereinafter cited as Imposing a Duty to Warn].

4. Tarasoff, 131 Cal. Rptr. at 34 (Clark, dissenting). See generally Smith, supra note 3; Stone, supra note $3 ; A$ Psychiatrist Who Knows or Should Know His Patient Intends Violence to Another Incurs a Duty to Warn, 7 CUM. L. REv. 551 (1977); Untangling Tarasoff: Tarasoff $v$. Regents of the University of California, 29 HASTINGS L.J. 179 (1977) [hereinafter cited as Untangling Tarasoff]; Psycotherapists' Obligation of Confidentiality Versus the Duty to Warn, 12 TULSA L.J. 747 (1977); Imposing a Duty to Warn, supra note 3.

5. Tarasoff, 131 Cal. Rptr. at 34 (Clark, dissenting). See generally Smith, supra note 3; Untangling Tarasoff, supra note 4; The Psychotherapist-Patient Privilege: Are Some Patients More Privileged Than Others?, 10 PAC. L.J. 801 (1979).

6. Tarasoff, 131 Cal. Rptr. at 24-25.

7. Id. 
8. See supra text accompanying note 1 .

9. W. PROSSER, HANDBOOK OF THE LAW OF TORTS, secs. 30-32 (4th ed. 1971); Restatement, Second, Torts sec. 299A (1965).

10. Tarasoff, 131 Cal. Rptr. at 22-23; Restatement, Second, Torst sec. 314.

11. Restatement, Second, Torts sec. 315 . Throughout this article, those relationships which fall under the first clause (a) will be referred to as "Type A" relationships, and those which fall under the second clause (b) will be referred to as "Type B" relationships. It is Type A relationships which are of central interest because the court clearly stated that its reasoning was based on the relationship between the therapists and Poddar, not between the therapists and Tarasoff. See Tarasoff, 131 Cal. Rptr. at 23.

12. Tarasoff, 131 Cal. Rptr. at 23-24.

13. Restatement, Second, Torsts secs. 315-19; F. W. Harper \& P. M. Kime, The Duty to Control the Conduct of Another, 43 YALE L.J. 886 (1934).

14. Restatement, Second, :Torsts secs. 316-19.

15. Harper \& Kime, supra note 13, at 904.

16. Semler v. Psychiatric Institute of D.C., 538 F.2d 121 (4th Cir. 1976); Underwood v. United States, 356 F.2d 92 (5th Cir. 1966); Fair v. United States, 234 F.2d 288 (5th Cir. 1956); Greenberg v. Barboar, 322 F.Supp. 747 (E.D. Pa. 1971); Merchants Nat'l Bank and Trust Co. v. United States, 272 F.Supp. 409 (D.N.D. 1967).

17. Meier v. Ross General Hospital, 69 Cal. 2d 420, 445 P.2d 519, 71 Cal. Rptr. 903 (1968); Vistica v. Presbyterian Hospital, 67 Cal. 2d 465, 432 P.2d 193, 62 Cal. Rptr. 577 (1967).

18. Under v. United States, 356 F.2d 92 (5th Cir. 1966); Fair v. United States, 234 F.2d 288 (5th Cir. 1956); Merchants Nat'l Bank and Trust Co. v. United States, 272 F. Supp. 409 (D.N.D.) 1967).

19. John v. State, 69 Cal. 2d 782, 447 P.2d 352, 73 Cal. Rptr. 240 (1968); Morgan v. Yuba, 230, 230 Cal. App. 2d 938, 41 Cal. Rptr. 508 (1964).

20. Ponchar v. Brackett, 246 Cal. App. 2d 769, 55 Cal. Rptr. 59 (1966); Ellis v. D'Angelo, 116 Cal. Ap. 2d 310, 253 P.2d 675 (1953). 
21. See, respectively, Kaiser v. Suburban Transp. System, 165 Wash. $2 \mathrm{~d}$ 461, 398 P.2d 14 (1965); Freese v. Lemmon, 210 N.W.2d 576 (Iowa 1973).

22. David v. Rodman, 147 Ark. 385, 227 S.W. 612 (1921); Hofmann v. Balckman, 241 So. 2d 752 (Fla. Dist. Ct. App. 1970); Skilling sv. Allen, 143 Minn. 323, 173 N.W. 663 (1919); Edwards v. Lamb, 69 N.H. 599, 45 A. 480 (1899); Wojcik v. Aluminum Co. of America, 18 Misc. 2d 740, 183 N.Y.S.2d 351 (1959); Jones v. Stanko, 118 Ohio St. 147, 160 N.E. 456 (1928).

23. We are not claiming that the courts articulated this principle, only that the principle captures the essential elements of the doctrine of special relationships as it has been applied in their decisions cited above.

24. Harper \& Kime, supra note 13 , at 888.

25. D. E. Orlinsky \& K. I. Howard, The Relation of Process to Outcome in Psycotherapy, in HANDBOOK OF PSYCHOTHERAPY AND Behavior Change 284 (S. Garfield \& A. Bergin 2d ed. 1978) [hereinafter cited as HANDBOOK].

26. B. Wolman, Dictionary of Behavioral Sciences 304 (1973); H. Strupp, Psychotherapy Research and Practice: An Overview, in HANDBOOK, supra note 25, at 3.

27. Tarasoff, 131 Cal. Rptr. at 27.

28. Id. at 24-25 \& n.10. See also J. Monahan, Predicting Violent BEHAVIOR 69-92 (1981); Cocozza \& Steadman, supra note 3; Stone, supra note 3; Untangling Tarasoff, supra note 4; Imposing a Duty to Warn, supra note 3.

29. In addition, there appear to be no data to support the hypothesis that warnings would decrease the probability of harm. For a further discussion related to this issue, see text following note 39 infra.

30. Wolman, supra note 26 , at 304 .

31. See generally, A. E. Bergin \& M. J. Lambert, The Evaluation of Therapeutic Outcomes, in HANDBOOK, supra note 25, at 139; J. T. Landman \& R. M. Dawes, Psycotherapy Outcome, 37 AMERICAN PSYCHOLOGIST 504 (1982).

32. See generally, Bergin \& Lambert, supra note 31; Landman \& Dawes, supra note 31. 
33. R. Novaco, Anger \& Coping With Stress: Cognitive Behavioral Interventions, in COGNITIVE BEHAVIOR THERAPY 135 (J. Foreyt \& D. Rathjen eds. 1978).

34. See, e.g., WIS. STAT. ch. $51.20(1)$.

35. Where the Public Peril Begins: A Survey of Psychotherapists to Determine the Effects of Tarasoff, 31 STAN. L. REv. 165, 176-77 (1978).

36. See, e.g., The Declaration of Hawaii, in PSYCHIATRIC ETHICS app., para. 8 (S. Blck \& P. Chodoff eds. 1981); Specialty Guidelines for the Delivery of Services by Clinical Psychologists, 36 AMERICAN PSYCHOLOGIST 640, para. 2.3.5 (1981).

37. See Tarasoff, 131 Cal. Rptr. at 33 (Mosk, concurring and dissenting).

38. When referring to predictions in the first and weakest sense, we will speak of a person identifying an expectation. The term "foretel" will be used to describe the process of identifying an expectation which proves to be accurate.

39. See supra note 28 and accompanying text.

40. See sources cited supra note 4.

41. Monahan, supra note 28 , at $112-16$.

42. Restatement, Second, Torts sec. 314, at 116.

43. McIntosh v. Milano, 168 N.J. 466, 403 A.2d 500 (1979). 